\title{
THE EFFECT OF TOURISM ACCESSIBILITY PERCEPTION TOWARDS TOURISTS VISITING INTENTION TO TOBA LAKE IN SAMOSIR DISTRICT
}

\author{
Dina Wati Veronika Napitupulu ${ }^{(1) *}$, Fitri Rahmafitria ${ }^{(2)}, \operatorname{Rosita}^{(3)}$ \\ (1) (2) (3) Universitas Pendidikan Indonesia \\ dinawatina70@gmail.com,rahmafitiria@upi.edu,rosita1019@upi.edu
}

\begin{abstract}
This study aims to see the effect of perceptions received by tourists visiting intention to Toba Lake, Samosir Regency. A quantitative approach method was used by using statistical data in multiple regression analysis. The population was domestic tourists and the sample was 325 respondents who were obtained using random sampling techniques. The results were divided into (1) a significant effect and positive destination accessibility and simultaneously on the intention in tourist visits 2) the ability of the independent variables in explaining the related variables was $53.8 \%$ the remaining $46.2 \%$ from other variables not discussed in this study 3 ) the influence of accessibility variable on tourists' visiting intention is strong. From these results it can be concluded that accessibility according to the Apollo concept needs to be improved by the manager of tourist destinations at Toba Lake because the role of accessibility affects the intention to visit tourists to Toba Lake.
\end{abstract}

Keywords: Real Accessibility, Destination Accessibility, and Visiting Intention

\section{INTRODUCTION}

The Indonesian government continues to improve tourism development because the tourism sector contributes to increasing the country's foreign exchange in the midst of the world economic turmoil (Kemenparekraf, 2019). President Joko Widodo initiated a plan to accelerate the development of super-priority tourist destinations, namely five destinations, namely Toba Lake, Borobudur, Manado, Mandalika, and Labuan Bajo. Not only various developments are carried out in these super-priority destinations, but also in every local tourist attraction.

The plan aims to accelerate the development of tourism potential, make the destination attractive to local, international tourists, and promote a better life for the community (Kompas.com). One of the government's development priorities is Toba Lake in the northern part of North Sumatra. Various efforts have been made by the government to develop Toba Lake tourism. This can be seen from the existence of the Toba Lake festival as an annual agenda which is the flagship of the North Sumatra Provincial Government and has not succeeded in meeting the target of foreign and domestic tourist visits to all districts that surround Toba Lake evenly (Kompas.com) and the other visitor behavior.

Susanto \& Kotler (in Wiradiputra \& Brahmanto, 2016) that intention is a driving force that is strong internal stimulation and motivation also influenced by stimulation and positive feelings towards a product. The intention to visit is also similar to buying intention (Albayrak \& Caber, 2018). So, when tourists already have an intention to visit, it is possible that tourists will visit tourist destinations (Zeithaml et al. 1996 in Tassiello \& Tillotson, 2020). The intention to visit is 
also greatly influenced by accessibility. The convenience achieved by someone will motivate tourists to take a trip. This is in line with Cole's (2019) opinion that the easier travel services are accessed, the stronger one's intrinsic motivation will be to travel in leisure time. Accessibility is the ability and ease of tourists to reach their destination comfortably (AlKahtani et al., 2015). A tourist who already has an intention will determine the decision to visit. As research related to accessibility that has been done previously by Byrne, Wolch, and Zhang in (Wang et al., 2015) found that easy access is an important reason for preferring the use of local parks. When accessibility is fulfilled, tourists' actions to choose and travel are stronger because accessibility has a positive relationship with travel motivation and is useful for travel and hospitality businesses that will need better guidance in identifying accessibility thresholds that will be increased to generate travel engagement and behavior. Positives from tourists (Cole et al., 2019). Thus, the perception of accessibility is very important to understand and predict human behavior including the intention to visit these tourists (Kruger et al., 2007; Zondag \& Pieters, 2005 in (Wang et al., 2015).

Whereas accessibility does not only mean the ease of these aspects but the comfort and ability of tourists to reach their destination. It needs to be analyzed from the social, economic and psychological aspects of tourists in line with the accessibility concept of Mountaineering Apollo (2017). Therefore, the perception of accessibility will be related to the personalities of tourists, which of course can influence their perceptions of what is considered easily accessible (AlKahtani et al., 2015).

From various studies on tourism accessibility, most of them only focus on destination accessibility in the form of the availability of accessibility of transportation, accommodation, and services (Simanjuntak et al., 2018). Accessibility that needs to be researched for tourists consists of two general parts, namely including destination accessibility and real accessibility (Apollo, 2017). Destination accessibility is defined as the ability to provide visitors with appropriate access to a destination and offer the services necessary for a comfortable stay. Destination accessibility is a general thing that must be completed by the manager of a tourist area, such as the availability of public and special facilities needed by tourists.

Therefore destination accessibility is divided into factors of transportation networks and in site services. Von Rohrscheidt (2010) in Apollo, (2017) notes that accessibility for tourist are combination both of destination and real accessibility. Destination accessibility is closer to the main internal needs of tourists when traveling in a destination. The existence of Apollo accessibility concept has an advantage because it discusses in depth the actual accessibility that climbing tourists need.

In this concept, destination accessibility relates to transportation to tourist sites and tourist facilities. Meanwhile, real accessibility has five main aspects: social, economic, psychological, climatic conditions, and policies related to mountain climbing. Real accessibility (real accessibility) has not been widely studied in general, even though this convenience affects the intention of tourists to carry out tourism activities. So, accessibility that affects tourists is not only destination accessibility but real accessibility which also really needs to be analyzed because it can affect the intention to visit tourists if the accessibility standards are met (Apollo, 2017).

The relationship between perceived accessibility and visitor intention in the tourist area of Toba Lake is the core of this study. If observed based on data on the number of visitors to Samosir Regency, the 
area where the Toba Lake tourist area is located, there is an increase in the number of domestic and foreign visitors from 2016 to 2019 (Table 1).

This increase was possible due to the increasingly incessant promotion and development carried out by the Toba Lake Authority Implementing Agency (Badan Pelaksana Otorita Danau Toba). This agency was formed based on Presidential Regulation Number 49 of 2016 (Indonesian Presidential Regulation Number 49 of 2016 on Tourism Area Management Authority of Toba Lake, 2016) with the aim of maximizing tourism development in the Toba Lake region.

The following is data on tourist visits from 2016-2019 that have increased. obtained from the (BPS Samosir, 2019).

\begin{tabular}{ccc}
\hline \multirow{2}{*}{ YEAR } & \multicolumn{2}{c}{ AMOUNT } \\
\cline { 2 - 3 } & $\begin{array}{c}\text { DOMESTIC } \\
\text { TOURIST }\end{array}$ & $\begin{array}{c}\text { FOREIGN } \\
\text { TOURIST }\end{array}$ \\
\hline 2016 & 154.905 & 35.823 \\
\hline 2017 & 222.288 & 55.771 \\
\hline 2018 & 312.925 & 65.724 \\
\hline 2019 & 367.301 & 50.970 \\
\hline
\end{tabular}

Table. 1 Statistics of tourist visits to Samosir Regency

(Source: BPS Samosir, 2019)

However, if observed based on the quality of tourism infrastructure development, especially accessibility, data is obtained as shown in Figure 2.1 showing that the accessibility in the form of infrastructure in Samosir Regency is not optimal because there are still many road conditions that are damaged and even heavily damaged. If the percentage is $53.6 \%$, the road conditions are categorized as damaged and heavily damaged.

\begin{tabular}{llllll}
\hline District & \multicolumn{4}{c}{ Road Condition } & Total \\
\cline { 2 - 5 } & Good & $\begin{array}{l}\text { Mode- } \\
\text { rate }\end{array}$ & $\begin{array}{l}\text { Dama- } \\
\text { ged }\end{array}$ & $\begin{array}{l}\text { Heavily } \\
\text { Damaged }\end{array}$ & \\
\hline $\begin{array}{l}\text { Sianjur } \\
\text { Mulamula }\end{array}$ & 31,84 & 12,70 & 11,65 & 32,07 & 88,25 \\
\hline Harian & 14,18 & 3,95 & 3,27 & 9,65 & 31,06 \\
\hline Sitiotio & 8,98 & 1,95 & 10,48 & 27,03 & 48,44 \\
\hline Onan & 34,35 & 7,90 & 18,41 & 23,99 & 84,65 \\
\hline
\end{tabular}

\begin{tabular}{lccccc}
\hline Runggu & & & & & \\
\hline $\begin{array}{l}\text { Naing- } \\
\text { golan }\end{array}$ & 31,55 & 9,31 & 15,69 & 35,35 & 91,89 \\
\hline Palipi & 33,39 & 11,36 & 11,85 & 40,32 & 96,92 \\
\hline $\begin{array}{l}\text { Ronggur } \\
\text { Nihuta }\end{array}$ & 13,15 & 4,33 & 41,03 & 47,97 & 106,48 \\
\hline Pangururan & 54,21 & 14,93 & 27,05 & 28,67 & 124,87 \\
\hline Simanindo & 53,40 & 15,86 & 14,51 & 14,89 & 98,66 \\
\hline Jumlah & 275,06 & 82,29 & 153,92 & 259,94 & 771,21 \\
\hline
\end{tabular}

Table. 2 Road Condition in Samosir Regency Source: Samosir in Figures 2018 (www. samosirkab.go.id)

If observations are made based on data on accessibility conditions, these conditions are mainly due to poor quality and the number of visits that tend to increase, then the results of the study by Rossadi \& Wisayati (2018) have a different phenomenon.

They analyzed one indicator in the form of the influence between the quality of accessibility and intention to visit. The results showed that the better the accessibility to the destination, the higher the intention to visit. In addition, in the media media liputan 6.com, there is support for services and infrastructure that continues to be developed to support the movement of tourists to Toba Lake. This can be seen from the smooth running of crossing activities during Lebaran 2019.

Achievement of the level of tourist visits to Toba Lake is very dependent on meeting the needs of tourists in the form of amenities, accessibility, attractions, and activities. Travel intention will increase if accessibility related to tourist needs is provided properly. This is in line with the mountaineering tourism accessibility concept (Apollo, 2017) that people who will do challenging activities in nature will need challenging mobility and are greatly influenced by the availability of destination accessibility and real accessibility. Therefore, to further analyze the contribution of accessibility to the intention of tourists visiting Toba Lake, a study entitled: "The Effect of Tourism Accessibility Perceptions to Tourist Visiting Intention to Toba Lake, Samosir District". 
Dina Wati Napitupulu, Fitri Rahmafitria, Rosita: The Effect of Tourism Accessbility Towards Tourits Visiting Intention to Toba Lake Samosir District

\section{LITERATURE REVIEW}

\section{Definition of Tourist Perception}

Every tourist has a different view when traveling. This view is called perception because it has a different impression on each visitor. This feeling can form in physical and non-physical sensations of visitors. This view is reflected in the interpretation of attitudes towards tourist attractions, information and various tourist facilities (Keliwar \& Nurcahyo, 2015).

\section{Visiting Intention}

According to Munawwaroh \& Lubis (2018), intention to visit comes from a boost in consumers in the form of a person's desire to visit a destination that attracts attention. Philip Kotler et al. (in Munawwaroh \& Lubis, 2018), namely consumer buying intention can be compared with tourist intention.

Consumers or tourists, of course, have to consider various factors when deciding to visit, such as before buying. In tourism marketing, the desire to buy tourism products begins with a selection process, after encouraging the selection of tourists, the destinations to be visited are determined. The existence of a strong desire and driven by an action is called intention (Rahmafitria, 2020).

\section{Definition of Accessibility}

Tourism products are part of tourism marketing. In accordance with the definition according to Nasrullah (2020), it can be concluded that tourism marketing also has a role in engaging and finding out what tourists needs and wants in creating a favorable climate to generate sales. In this study, accessibility as a tourism product is very important to be researched in order to meet the wants and needs of tourists in tourist destinations.

The perceived accessibility of the travel industry was found to influence people's intrinsic motivation and identity. The more accessible the perceived travel service is, the stronger the intrinsic motivation and identifiable people demonstrating for leisure travel (Cole et al., 2019).

\section{The Apollo Accessibility Concept}

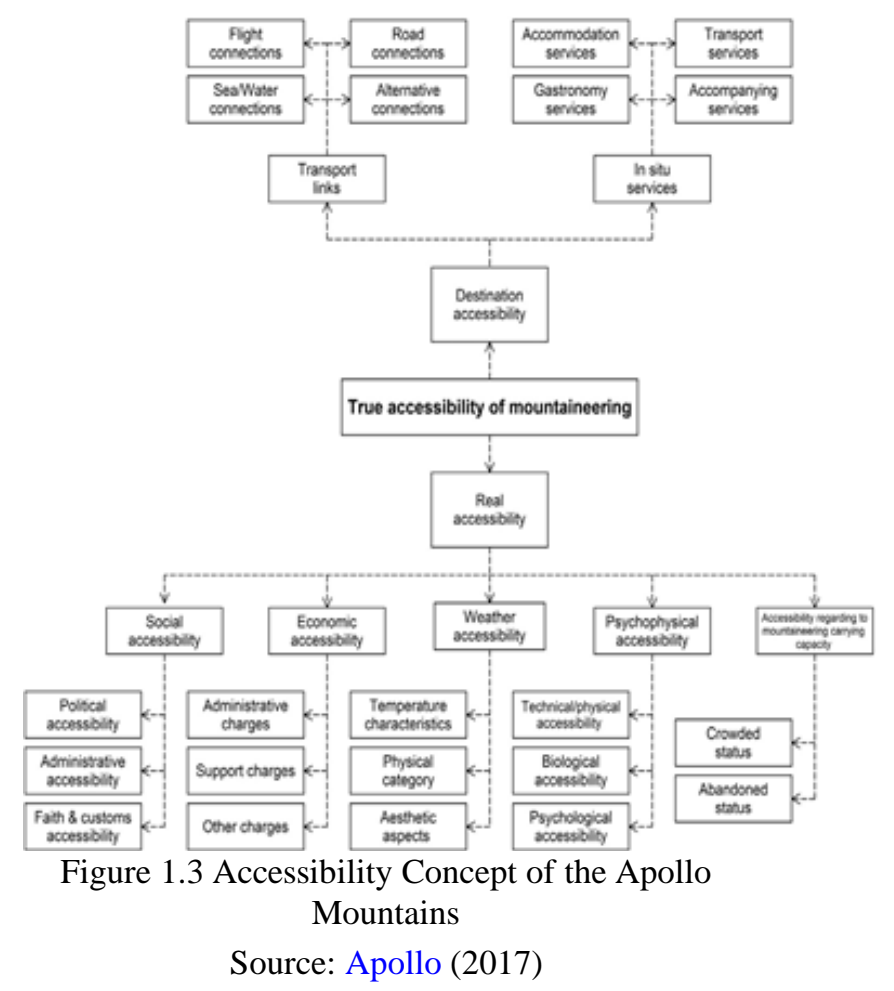

\section{Destination Accessibility}

According to Apollo (2017) destination accessibility is defined as the ability to provide suitable access for visitors to a destination and offer the necessary services for a comfortable stay. Munteanu in (Apollo, 2017) shows that destination accessibility in terms of transportation accessibility can include four aspects: spatial/territorial, economic, psychological, and social.

The term in site services (sometimes called 'spatial elements') includes all services and infrastructure necessary to enable tourism activities in a tourist destination (Rahmafitria, 2020). In site services include accommodation, gastronomy, and transportation (e.g. porters of goods and animals), all equipped with several basic levels and with accompanying services (Hall, 2005; Middleton, 1994 in Apollo 2017). 


\section{a. Transportation}

According to Shimizu \& Troung (in Ramadhanu, 2018) the progress of the tourism industry can be seen from the need for transportation that meets demand on the contrary, adequate transportation facilities can encourage the development of the tourism industry.

Furthermore to Tambunan (2009) tourists usually use three types of transportation to meet their needs, namely air transportation (international flights/domestic flights), sea transportation (regular routescharter /cruisers), and land transportation /bicycles, (off-road vehicles or motorbike, bus, train).

b. Services on Tourist Sites

The level of service available in the Himalayas on the Apollo accessibility concept varies, as does each mountain range located in the countries of the South. Most mountaineers have low requirements for the service and for them simple accommodation (sleeping in a regular guest house is better than in a tent), general gastronomy (eating at a local restaurant is mediocre), and simple transport services (using animals to transport equipment is better than carrying it yourself) is really sufficient.

Based on the above statement, the authors make the following statistical hypothesis:

H0: Perception of destination accessibility does not have a positive effect on tourist intention.

H1: Perception of destination accessibility has a positive influence on tourist intention to visit.

\section{Real Accessibility}

\section{a. Economy}

The economic accessibility of mountain climbing destinations depends on the financial possibilities of tourists. Economic accessibility plays an important role in mountain tourism today and can remain the most important element in the real accessibility of mountains in the future. Costs may reach a point that prevents many tourists from accessing the attraction, thus determining its availability. When a person wants to travel, he must also consider his income. If the income you have can satisfy your desire to travel, your intention to visit tourists will be even greater, and vice versa (Mu, 2019).

\section{b. Psychological}

Psychological accessibility can be expressed by the efforts of tourists who are willing to endure to reach their destination, but it is also influenced by the level of comfort they feel or the risks they bear. Potential tourists can decide that they don't want to visit a destination because that destination has a high crime rate. If tourists feel unsafe at a destination, they are less likely to want to take part in activities outside their accommodation facilities. Tourists who feel threatened or insecure have no intention in returning to a destination and are less likely to recommend the destination to others.

Therefore, the safety and security of tourists from crime from local residents is a prerequisite for tourists intentioned to visit the destination (George, 2003).

\section{c. Social}

In the concept of Apollo Accessibility, social accessibility related to political factors in the Himalayas can be a real limiting factor for the movement of climbers to climb in the mountains.

Based on this concept, the authors conclude that the political situation is the driving force for tourists to travel.

\section{d. Climate}

Weather is an external factor others who can determine the success of the expedition/trip (Savage \& Torgler, 2015 in Apollo 2017). Weather accessibility is concerned with the presence of meteorological conditions that enable mountaineers to successfully reach their destination and return safely. 
Dina Wati Napitupulu, Fitri Rahmafitria, Rosita: The Effect of Tourism Accessbility Towards Tourits Visiting Intention to Toba Lake Samosir District

Weather conditions also undergo dramatic changes over relatively short periods of time in mountainous areas and directly affect the success of mountain climbing Pomfret (in Apollo, 2017). According to de Freitas (in Apollo, 2017) the nature of the relationship between the weather environment and pleasant trips from outdoor recreational activities can be seen as a function of local conditions.

The human response to the weather is largely a matter of perception. By adopting de Freitas (in Apollo, 2017) 'climatic tourism perspective', some weather accessibility can be classified relative to the influence of weather parameters on human physiology (e.g. temperature), actual climbing conditions (e.g. rainfall, snow cover, wind, solar radiation), and aesthetic conditions (e.g. cloudy skies, visibility, length of day). Weather conditions are not only important for the mountain climbing activity itself, but also for doing it. Thus, it can be concluded that when tourists are about to travel, weather accessibility is their consideration to produce a pleasant experience.

Based on several previous statements and taking into account the various studies that have been done, the following hypothesis is proposed:

H2: Perception of real accessibility has a positive effect on tourist intention to visit.

H0: Perception of real accessibility does not have a positive effect on tourist intention.

H3: Perceptions of destination accessibility and real accessibility simultaneously have a positive effect on tourist intention to visit.

H0: Simultaneously, perceptions of destination accessibility and real accessibility do not have a positive effect on tourist intention to visit.

\section{RESEARCH METHOD}

The author uses quantitative methods for this research. Since observations about the interviewee's opinion are converted into numbers, statistical techniques can be used to analyze the results. Quantitative data is data in digital form or score data. This study uses quantitative analysis techniques and multiple regression analysis tools. This study will use a questionnaire survey method for data collection. In the questionnaire method, the questionnaire is used as a data collection tool to test the validity and reliability. After collecting research data, the next step is data processing. In this process, SPSS is used for statistical analysis techniques. The sampling technique used was purposive sampling, namely the technique of determining the sample with certain considerations (Sugiyono, 2016, hlm. 82).

In determining the sample size by following the calculations of Hair et al., (In Pratita et al., 2018) namely the number of questions multiplied by 10 . There are 18 indicator items in this study, so that the sample size is 180. Questionnaires were distributed for one month, which is in October 2020.

The author uses an instrument in the form of a closed questionnaire using a Likert scale (Sugiyono, 2016, hlm. 142). The questionnaire is divided into four parts. First, it contains questions about the characteristics of respondents such as; age, gender, level of education, and occupation, the choice of transportation used to Toba Lake, the costs incurred for traveling. Second, contains 8 questions related to destination accessibility referring to reference sources Chen et al., 2014; Wang et al., 2015; Apollo, 2017; Ramadhanu, 2018; Rossadi \& Widayati, 2018; Cole et al., 2019. Third, it contains 7 statements of real accessibility according to references to George, 2003; Wang et al., 2015; Apollo, 2017; Brown et al., 2018. Fourth, contains 
three statements to measure tourist intention to visit which refer to Munawwaroh \& Lubis, 2018.

In this study, researchers combined SPSS computer technology with the Pearson bivariate test. After the authors collect data and information, the authors will systematically manage and compile the data obtained in accordance with existing problems, analyze the data, and use quantitative methods for data analysis. The data analysis model in this study uses regression analysis, which is used to study the dependence of the dependent variable (bound) and one or more independent variables (free) to predict the overall mean or mean of the dependent variable. Before doing the analysis, to get a high score, the writer needs to test the data collection tools used. The analytical test method used is validity and reliability.

\section{RESEARCH RESULT Respondent Profile}

From the 325 respondents, $63.4 \%$ were dominated by women. The age range was dominated by respondents aged 17-22 years as much as $78.5 \%$. Furthermore, the educational background of the respondents was dominated by respondents from the SD/SMP/SMA levels as much as $67.4 \%$. Furthermore, the occupation of respondents is dominated by students with the status of students as much as $69.5 \%$.

Income was dominated by respondents who had low incomes ranging from $\mathrm{Rp}$ 500,000 to $\mathrm{Rp} 2,000,000$ as much as $62.8 \%$. This is evident from the data respondents generally came from among students/students. For tourism expenses incurred by respondents, it was dominated by respondents who spent tourism costs Rp 500,000 - Rp 1,000,000 as much as $67.4 \%$. The origin of the respondents was dominated by respondents from Medan and its surroundings as much as $83.7 \%$.

\section{Multiple Linear Regression Analysis Test}

The results of data processing obtained a constant coefficient value of 3.710, regression coefficient of destination accessibility to visiting intentions of 0.174 and a regression coefficient of real accessibility of 0.131 . Based on these data results, the regression equation can be formulated as follows:

$$
\begin{gathered}
Y=a+b_{1} X_{1}+b_{2} X_{2}+\ldots \ldots+b_{n} X_{n} \\
Y=3.710+0,174 X_{1}+0,131 X_{2}
\end{gathered}
$$

Constant value 3.710 , shows that if the destination accessibility and real accessibility variables are not changed, the intention to visit tourists to Toba Lake, Samosir Regency is equal to. The value of the destination accessibility regression coefficient means that if the destination accessibility variable (X1) increases by $1 \%$, then assuming the real accessibility variable (X2) and the constant (a) are zero (0), the intention to visit tourists to Toba Lake, Samosir Regency will increase by. Destination accessibility (X1) variable contributes positively to tourist intention to visit. So, that the better the destination accessibility to Toba Lake, Samosir Regency, the intention to visit tourists will increase $3.7100,174,0,174$.

\section{a. Testing Hypothesis 1 (H1)}

From the results of the test conducted, it shows a smaller significance value so that the hypothesis is partially accepted. This means that there is a positive influence of variable $\mathrm{X}$ on $\mathrm{Y}$ or there is a positive influence of destination accessibility on tourist intention to visit. The effect of destination accessibility on tourist intention is $0.000<0.05$ OR $\mathrm{t}$ count> $t$ table $(9,909>7,763$ then $\mathrm{H} 1$ is accepted and $\mathrm{H} 0$ is rejected).

\section{b. Testing Hypothesis 2 (H2)}

From the results of the tests carried out, it shows a smaller significance value so that the hypothesis is accepted, which means that there is a positive 
Dina Wati Napitupulu, Fitri Rahmafitria, Rosita: The Effect of Tourism Accessbility Towards Tourits Visiting Intention to Toba Lake Samosir District

influence of variable $\mathrm{X}$ on $\mathrm{Y}$ or there is a positive effect of real accessibility on tourist intention. The effect of real a. Testing Hypothesis 3 (H3) with the F test accessibility on tourist intention is 0.000 $<0.05$ OR $t$ count $>\mathrm{t}$ table $(8.221>7,763$ then $\mathrm{H} 2$ is accepted and $\mathrm{H} 0$ is rejected).

Table 3. F Test Results

\begin{tabular}{|c|c|c|c|c|c|c|}
\hline \multicolumn{7}{|c|}{ ANOVA $^{\mathrm{a}}$} \\
\hline Model & & Sum of Squares & Df & Mean Square & $\mathrm{F}$ & $\mathrm{Sig}$ \\
\hline \multirow[t]{3}{*}{1} & Regression & 296.012 & 2 & 148.006 & 189.707 & $.000^{\mathrm{b}}$ \\
\hline & Residual & 251.218 & 322 & .780 & & \\
\hline & Total & 547.231 & 324 & & & \\
\hline
\end{tabular}

a. Dependent Variable: Y

b. Predictors: (Constant), X2, X1

Source: Author processed (2020)

It is known that $\mathrm{H} 3$ is accepted or destination accessibility and real accessibility simultaneously have a positive and simultaneous influence on tourist intention to visit. This can be seen from the significance value of destination accessibility and real accessibility simultaneously affects intention by $0.000<0.05$, the $\mathrm{F}$ value of $189.707>\mathrm{F}$ Table 0.006 .

\section{b. Determination Coefficient Test}

The Adjusted R Square value shows a percentage of 0.538 . This means that the dependent variable can only explain the independent variable as much as $53.8 \%$. The explanation of the other variables of $46.2 \%$ is not fully discussed in this study.

\section{Table 4. The results of the determination}

\begin{tabular}{llccc} 
& \multicolumn{3}{c}{ Coefficient test } \\
\hline & & \multicolumn{3}{c}{ Model Summary $^{\mathbf{b}}$} \\
Model & $\mathrm{R}$ & $\mathrm{R}$ Square & Adjusted R Square & Std. Error of the Estimate \\
1 & $.735^{\mathrm{a}}$ & .541 & .538 & .88328 \\
a. Predictors: (Constant), X2, X1 & & & \\
\hline
\end{tabular}

b. Dependent Variable

Source: Author processed (2020)

\section{DISCUSSION}

Researchers conduct a depth interview to explain the results of the study in detail in order to explain the results of testing the hypothesis that has been proposed by the researcher.

1. The influence of Destination accessibility on tourist intention to visit Toba Lake, Samosir Regency

The destination accessibility indicator in this study is in accordance with the Apollo concept (2017) which consists of the availability of transportation networks/transport links and the availability of services on tourist sites/in site services. This shows that the findings in this study are the increasing availability of indicators in destination accessibility, the higher the intention to visit tourists to Toba Lake, Samosir Regency. The results of this study are in line with the findings of research by Rossadi \& Widayati (2018) that accessibility and amenities in tourism have a positive influence on tourist intention to visit.

In addition, (Cole et al., 2019) found that the easier accessibility in 
destinations felt by tourists, the greater the desire of tourists to participate in their spare time. The results of this study are in line with Soekadijo's theory Hidayat (Handayani et al., 2019) which states that the conditions of public roads and access roads determine whether or not tourist attractions are good and easy for tourists to reach. However, indicators in the form of road quality are not strong enough to measure the accessibility of Apollo destinations because there are several other indicators that are not discussed in this study but are discussed in previous research by Mckercher (2008) and IHME (2013) that the things that also affect intention tourists, namely the distance traveled, travel time.

However, there is something intentioning from the destination accessibility indicator that as long as there is transportation available at tourist destinations, tourists will still be intentioned to visit the Toba Lake destination. This is indicated by the average response of $76.4 \%$ of respondents who have the perception that the availability of transportation in Toba Lake is good and complete so that they have the desire to visit Toba Lake.

This is in line with the findings of previous research by (Tambunan, 2009) that transportation is an important consideration in the progress of tourism. In addition, the availability of services on tourist sites, including the complete facilities and infrastructure at Toba Lake, has a positive influence on tourist intention. This study supports the findings made by (Rossadi \& Widayati, 2018). (Handayani et al., 2019), that adequate facilities and infrastructure can meet the needs of tourists while in tourist destinations in the form of hospitals, availability of banks, internet networks, etc. have a positive influence on tourist intention.

However, these findings contradict previous research conducted by (Syahrul,
2014) that facilities do not have a positive effect on tourist intention to visit. Lodging is also an indicator in this study, the results show that there is an influence on the availability of lodging options in the form of guest houses, homestays, and hotels. This is in line with the findings of the research by (Simanjuntak et al., 2018) that the availability of transportation, restaurants and lodging /accommodation is something that tourists will pay attention to in determining which tourist destinations are worth visiting. In addition, tourists who want to visit tourist destinations also need opportunities to obtain information. Respondents studied in this study predominantly agree that access to information on Toba Lake is good so that it raises their intention to visit. From the discussion of destination accessibility, it can be concluded that each indicator of the Apollo Accessibility Concept (2017) has a positive and significant effect on the intention of visitors to Toba Lake in Samosir Regency.

\section{The Influence of Real Accessibility on Tourists' Visiting Intention in Toba Lake, Samosir Regency \\ The actual accessibility indicators} in this study are in line with the concept of Apollo (2017) which includes economic, social, psychological, and climate aspects. The higher the real accessibility index, the higher the intention of tourists to Toba Lake, Samosir Regency. This study proves that from an economic aspect it affects the intention of tourists to Toba Lake, Samosir Regency. However, the results of this study contradict previous research conducted by (Syahrul, 2014) which showed that income did not have a significant effect on the intention of tourists visiting Bengkulu Beach attractions. However, the results of this study support previous research by Tambunan (2009) which shows that financial factors have a positive effect on travel decisions of potential tourists. 
And the results of research on social aspects are in the form of customary rules that can hinder the movement of tourists. The dominant respondents agreed that Toba Lake is free from binding customary rules. So it can be concluded that when there are customary rules it can hinder their desire to travel. The psychological aspect in this research, which is the safety and security of tourists, affects the intention of tourists. This is evidenced by the average percentage of respondents' responses of $81 \%$ which state that the tourist area of Toba Lake is safe from human crime and road conditions are safe from accidents. Therefore, these results also support (Hermawan, 2017) previous research on the importance of tourist safety. The social aspect in this study in the form of the presence/absence of customary rules can be taken into account by tourists when they want to decide which tourist destinations to visit. This is in line with the opinion (George, 2003) that freedom from community cultural values is an important factor for potential tourists. On the other hand, the results of research on the climate/weather aspect show that weather conditions will not change the preferences for changes in tourist activity. So it can be concluded that weather conditions will not reduce the intention to visit tourists to Toba Lake, Samosir Regency.

\section{The Influence of True Accessibility (Destination and Real Accessibility) on Tourist Visiting Intention in Toba Lake, Samosir Regency}

Apollo's concept of true accessibility, which consists of destination accessibility and real accessibility, simultaneously has a positive influence on tourist intention to visit. The results of the research in the multiple regression test show that the constant value of the respondent's intention to visit is already high at 3,710 if there is no addition of destination accessibility and real accessibility. However, if the concept of true accessibility is adequately equipped, it will increase tourist intention. The existence of a simultaneous effect of true accessibility on tourist intention to visit supports previous research, in which there are indicators that are the same as the Apollo Accessibility concept (2017). This research was conducted by (Rossadi \& Widayati, 2018), (Arizky Kautsar Ramadhanu, 2018), and (Handayani et al., 2019). Previous research results indicate the importance of destination accessibility in the form of service availability on tourist sites, transportation networks, economic aspects, social aspects, and psychological aspects. However, the results of this study also contradict research conducted by (Syahrul, 2014) which shows that facilities and income do not have a positive effect on tourist intention.

The availability of services at tourist attractions is an important factor for tourists because it can create experiences for these tourists so that tourists will have an intention to visit and can even recommend their relatives, relatives and friends to travel to tourist attractions that will or have alreadyhe visited. Intention will arise when consumers or tourists have various considerations. Respondents in this study have shown a high intention to visit plus a stimulus/encouragement from the availability of true accessibility according to the Apollo concept. Although the results of the research show that there is a positive influence on the independent variables simultaneously, it should be noted that the adjusted R Square value of 0.538 means that only $53.8 \%$ of the independent variables are able to explain the accessibility of tourism in Samosir Regency.

\section{CONCLUSION}

Perceptions of destination accessibility and accessibility variables actually have a big effect on the intention 
of tourists who want to visit Toba Lake, Samosir Regency. Based on the simultaneous hypothesis testing (Test F) on the variable destination accessibility and real accessibility, the results show that there is a significant influence of these two variables simultaneously on the intention to visit tourists to Toba Lake, Samosir Regency. And analysis of the coefficient of determination obtained Adjusted R Square value of 0.538 or $53.8 \%$. This research is categorized as sufficient to explain accessibility.

Further researchers can use the results of this study as a reference. In addition, it is necessary to add other variables and indicators that should be taken into consideration in further research regarding the relationship of destination accessibility and real accessibility to the intention to visit tourists to tourist destinations. And practitioners in the tourism sector can conduct research related to the role of accessibility to visit tourists' intention in another super priority tourist destination. For Toba Lake destination managers, Samosir Regency needs to pay attention to the high intention to visit Samosir tourist destinations.

\section{REFERENCES}

Albayrak, T., \& Caber, M. (2018). Examining the relationship between tourist motivation and satisfaction by two competing methods. Tourism Management, 69(June), 201-213. https://doi.org/10.1016/j.tourman.201 8.06.015

AlKahtani, S. J. H., Xia, J., Veenendaaland, B., Caulfield, C., \& Hughes, M. (2015). Building a conceptual framework for determining individual differences of accessibility to tourist attractions. Tourism Management Perspectives, 16 , 28-42. https://doi.org/10.1016/j.tmp.2015.05. 002

Apollo, M. (2017). The true accessibility of mountaineering: The case of the High Himalaya. Journal of Outdoor Recreation and Tourism, 17(August 2015), 29-43. https://doi.org/10.1016/j.jort.2016.12. 001

Arizky Kautsar Ramadhanu. (2018). Analisis Persepsi Kemanfaatan, Kemudahan, Kualitas Dan Harga Transportasi Online Sebagai Sarana Penunjang Aksesibilitas Wisatawandi Kota Malang. Jurnal Administrasi Bisnis (JAB)|, 60(2), 64-73.

Badan Pusat Statistik (BPS). (2020). Diakses dari: https://samosirkab.bps.go.id/

Brown, P., Daigneault, A. J., Tjernström, E., \& Zou, W. (2018). Natural disasters, social protection, and risk perceptions. World Development, 104, 310-325.

https://doi.org/10.1016/j.worlddev.20 17.12.002

Chen, Y. C., Shang, R. A., \& Li, M. J. (2014). The effects of perceived relevance of travel blogs' content on the behavioral intention to visit a tourist destination. Computers in Human Behavior, 30, 787-799. https://doi.org/10.1016/j.chb.2013.05. 019

Cole, S., Zhang, Y., Wang, W., \& Hu, C. ming. (2019). The influence of accessibility and motivation on leisure travel participation of people with disabilities. Journal of Travel and Tourism Marketing, 36(1), 119-130. https://doi.org/10.1080/10548408.201 8.1496218

George, R. (2003). Tourist's perceptions of safety and security while visiting Cape Town. Tourism Management, 24(5), 575-585. https://doi.org/10.1016/S02615177(03)00003-7

Handayani, S., Khairiyansyah, \& Wahyudin, N. (2019). Fasilitas, Aksesibilitas Dan Daya Tarik Wisata Terhadap Kepuasan Wisatawan. 
Dina Wati Napitupulu, Fitri Rahmafitria, Rosita: The Effect of Tourism Accessbility Towards Tourits Visiting Intention to Toba Lake Samosir District

Jurnal Ilmiah Manajemen Dan Bisnis, 20(2), 123-133.

Hermawan, H. (2017). Pengaruh daya tarik wisata, keselamatan, dan sarana wisata terhadap kepuasan serta dampaknya terhadap loyalitas wisatawan: studi Community Based Tourism di Gunung Api Purba Nglanggeran. Media Wisata, 15(1).

IHME. (2013). No Title جهاى زيرزمينى .آب و 11-1, خاك.

Indonesian Presidential Regulation Number 49 of 2016 on Tourism Area Management Authority of Lake Toba. (2016).

Keliwar, S., \& Nurcahyo, A. (2015). Jurnal Manajemen Resort dan Leisure Vol. 12, No. 2, Oktober 2015 MOTIVASI DAN PERSEPSI PENGUNJUNG TERHADAP OBYEK WISATA DESA BUDAYA PAMPANG DI SAMARINDA. Jurnal Manajemen Resort, 12(2), 10-27.

Kemenparekraf. (2019). Panduan Potensi Pembangunan Sektor Pariwisata dan Ekonomi Kreatif. Retrieved from: https://www.kemenparekraf.go.id/rag am-pariwisata/Panduan-Potensi-

Pembangunan-Sektor-Pariwisata-danEkonomi-Kreatif

Kompas.com. (2019). 6 Langkah Pemerintah Tingkatkan Pariwisata Indonesia. Retrieved from: https://amp-kompas-

com.cdn.ampproject.org/v/s/amp.kom pas.com/travel/read/2019/03/19/1107 00827/6-langkah-pemerintahtingkatkan-devisa-pariwisataindonesia?amp_js_v=a6\&amp_gsa $=1$ \&usqp=mq331AQHKAFQArABIA\% 3D\%3D\#aoh=16187169914847\&amp _ct $=1618717012511 \& \mathrm{csi}=1 \&$ referrer $=\mathrm{https} \% 3 \mathrm{~A} \% 2 \mathrm{~F} \% 2 \mathrm{Fwww}$.google.co m\&amp_tf=Dari $\% 20 \% 251 \% 24 \mathrm{~s}$

Mckercher, B. (2008). Movements. Klenosky 2002, 208-224.

Mu, A. (2019). 済無No Title No Title. Journal of Chemical Information and Modeling, 53(9), 1689-1699.
https://doi.org/10.1017/CBO9781107 415324.004

Munawwaroh, P. R., \& Lubis, E. E. (2018). Pengaruh Terpaan Media pada Akun Instagram @exploresiak terhadap Minat Kunjungan Wisata ke Siak Sri Indrapura. Jom Fisip, 5(1), $1-13$.

Nasrullah,dkk. (2020). Pemasaran Pariwisata: Konsep Perencanaan dan Implementasi.Jakarta: Yayasan Kita Menulis

Pratita, B. W. A., Heri Pratikto, \& Sutrisno. (2018). Analisis FaktorFaktor Yang Memengaruhi Keputusan Pembelian Pelanggan di Kober Bar Malang. Jurnal Pendidikan: Teori, Penelitian, Dan Pengembangan, 3(4), 497-503.

Rahmafitria, F., Pearce, P. L., Oktadiana, H., \& Putro, H. P. (2020). Tourism planning and planning theory: Historical roots and contemporary alignment. Tourism Management Perspectives, 35, 100703.

Rahmafitria, F., Sukmayadi, V., \& Purboyo, H. (2020, May). The Real and Actual Tourism Accessibility in Protected Areas. In IOP Conference Series: Earth and Environmental Science (Vol. 501, No. 1, p. 012047). IOP Publishing.

Rossadi, L. N., \& Widayati, E. (2018). Pengaruh Aksesabilitas, Amenitas, dan Atrakasi Wisata Terhadap Minat Kunjungan Wisatawan ke Wahana Air Balong Waterpark Bantul Daerah Istimewa Yogyakarta. Journal of Tourism and Economic, 1(2), 109116.

Simanjuntak, C., Leli Kusuma Dewi, L. G., \& Susrami Dewi, N. G. A. (2018). Penyediaan Aksesibilitas Bagi Wisatawan Penyandang Disabilitas Oleh Stakeholder Di Kotamadya Denpasar Kecamatan Denpasar Selatan. Jurnal IPTA, 6(1), 55. https://doi.org/10.24843/ipta.2018.v0 6.i01.p06 
Dina Wati Veronika Napitupulu, Fitri Rahmafitria, Rosita: The Effect of Tourism Accessbility Towards Tourists Visiting Intention to Toba Lake in Samosir District

Syahrul, A. R. (2014). Pengaruh Daya Tarik, Fasilitas Dan Aksesibilitas Terhadap Keputusan Wisatawan Asing Berkunjung Kembali Ke Aloita Resort Di Kab. Kep. Mentawai. Jurnal Pelangi, 7(1), 71-82. https://doi.org/10.22202/jp.v7i1.193

Sugiyono. (2016). Metode Penelitian Kuantitatif, Kualitatif dan R\&D. Bandung: Alfabeta

Tambunan, N. (2009). Posisi Transportasi Dalam Pariwisata. Majalah Ilmiah Panorama Nusantara, VI(Bps 2008), 39-48

Tassiello, V., \& Tillotson, J. S. (2020). How subjective knowledge influences intention to travel. Annals of Tourism Research, 80(November 2019). https://doi.org/10.1016/j.annals.2019. 102851

Wang, D., Brown, G., \& Liu, Y. (2015). The physical and non-physical factors that influence perceived access to urban parks. Landscape and Urban Planning, 133, 53-66. https://doi.org/10.1016/j.landurbplan. 2014.09.007

Wiradiputra, F. A., \& Brahmanto, E. (2016). Analisis Persepsi Wisatawan Mengenai Penurunan Kualitas Daya Tarik Wisata Terhadap Minat Berkunjung. Pariwisata, III, No.2(2), 129-137 ISSN: 2355-6587. 
52 - JITHOR Vol.4, No.1, April 2021 - eISSN : 2654-4687 pISSN : 2654-3894 